\title{
HUBUNGAN LITERASI LINGKUNGAN DAN LITERASI MATEMATIS TERHADAP KEMAMPUAN COMPUTER SELF EFFICACY
}

\author{
M. Syaif Amrullah Alqusyairi ${ }^{* 1}$, Farida $^{2}$, Suherman $^{3}$ \\ 1,2,3 Universitas Islam Negeri Raden Intan Lampung \\ erysyaif@gmail.com*1, farida@ radenintan.ac.id ${ }^{2}$, suherman@ radenintan.ac.id ${ }^{3}$
}

\begin{abstract}
The purpose of this study is to determine the relationship between environmental literacy and mathematical literacy on the ability of students' Computer Self Efficacy. This quantitative study uses a Correlational Design research design. The data collection techniques in this study were environmental literacy tests, mathematical literacy tests, and a Computer Self Efficacy ability questionnaire. The data analysis technique used is Simple and Multiple Linear Regression. Based on the results obtained from research and calculations of Simple and Multiple Linear Regression analysis, it was concluded that there is a relationship between environmental literacy and the ability of Computer Self Efficacy of students, there is a relationship between mathematical literacy and the ability of Computer Self Efficacy of students, and there is a relationship between environmental literacy and mathematical literacy with the ability of students' Computer Self Efficacy. The magnitude of the influence of environmental literacy and mathematical literacy on the ability of Computer Self Efficacy is $39.2 \%$.
\end{abstract}

Keywords: Environmental Literacy, Mathematical Literacy, Computer Self Efficacy Ability

\begin{abstract}
Abstrak
Tujuan penelitian ini yaitu untuk mengetahui hubungan literasi lingkungan dan literasi matematis terhadap kemampuan Computer Self Efficacy peserta didik. Penelitian kuantitatif ini menggunakan desain penelitian Correlational Desaign. Teknik pengumpulan data dalam penelitian ini yaitu tes literasi lingkungan, tes literasi matematis, dan angket kemampuan Computer Self Efficacy. Teknik analisis data yang digunakan yaitu Regresi Linier Sederhana dan Berganda. Berdasarkan hasil yang diperoleh dari penelitian dan perhitungan analisis Regresi Linier Sederhana dan Berganda, diperoleh kesimpulan bahwa terdapat hubungan antara literasi lingkungan dengan kemampuan Computer Self Efficacy peserta didik, terdapat hubungan antara literasi matematis dengan kemampuan Computer Self Efficacy peserta didik, dan terdapat hubungan antara literasi lingkungan dan literasi matematis dengan kemampuan Computer Self Efficacy peserta didik. Besarnya pengaruh literasi lingkungan dan literasi matematis terhadap kemampuan Computer Self Efficacy yaitu sebesar 39,2\%.
\end{abstract}

Kata Kunci: Literasi Lingkungan, Literasi Matematis, Kemampuan Computer Self Efficacy

Received: April 30, 2021 / Accepted: June 24, 2021 / Published Online: August 30, 2021 
Jurnal Lebesgue: Jurnal Ilmiah Pendidikan Matematika, Matematika dan Statistika

M. Syaif Amrullah Alqusyairi, Farida, Suherman

Volume 2, No. 2, Agustus 2021 hal.153-165

DOI Artikel : 10.46306/lb.v2i2.62

\section{PENDAHULUAN}

Kemampuan peserta didik tentang pemahaman dan penafsiran yang diaplikasikan secara efektif dalam mengatasi, meningkatkan, dan mempertahankan keadaan lingkungan adalah kemampuan literasi lingkungan (Afrianda et al., 2019; Yusliani \& Yanti, 2020). Literasi lingkungan berguna untuk menyiapkan peserta didik yang dapat memahami serta mengatasi berbagai masalah yang terjadi dilingkungannya (Ilhami, 2019; Supriyanto, 2020). Literasi lingkungan membangun kesadaran speserta didik untuk melestarikan lingkungan supaya selalu terjaga keseimbangannya (Komariah et al., 2017; Mujib et al., 2019). Kesadaran ini dapat diartikan sebagai sikap peka terhadap lingkungan dan mempunyai sikap tanggap dalam memberi solusi terhadap persoalan yang di lingkungan (Hekmah et al., 2019; Nugraha et al., 2021). Melalui penilaian literasi lingkungan peserta didik diharapkan dapat mengetahui informasi tentang tingkat literasi lingkungan seseorang (khususnya peserta didik) (Rahmah et al., 2019; Wijaya, 2019). Selain literasi lingkungan, literasi matematis juga perlu dikuasai peserta didik ketika belajar matematika.

Literasi matematis dibutuhkan peserta didik dalam menghadapi dan menyelesaikan permasalahan dalam ilmu matematika (Ginanjar \& Widayanti, 2019; Pamungkas \& Franita, 2019; Suherman et al., 2020). Literasi matematis dapat membantu dalam menafsirkan matematika dalam berbagai konteks, termasuk kemampuan penalaran secara matematis dan menggunakan konsep, prosedur, dan fakta untuk menggambarkan, menjelaskan, atau memperkirakan fenomena atau kejadian (Hidayati et al., 2020; Indrawati \& Wardono, 2019). Literasi matematis juga berguna dalam menentukan keputusan dalam menyelesaikan suatu permasalahan (Janah et al., 2019; Prabawati et al., 2019). Literasi matematis yang baik membutuhkan komitmen peserta didik dalam memilih cara belajar yang bermakna dan lebih dari sekedar menghafal (Hapsari et al., 2019; Madyaratri et al., 2019; Sukaesih et al., 2020), dan membutuhkan motivasi dalam mencari hubungan konseptual antara pengetahuan yang dimiliki dengan yang dipelajari (Fatwa et al., 2019; Komarudin et al., 2020). Literasi matematis yang baik dapat meningkatkan kemampuan memecahkan masalah, mengklasifikasikan dan mengkatagorikan informasi, bekerja dengan konsep-konsep abstrak serta melakukan perhitungan matematika secara sistematis dan kompleks (Lestariningsih et al., 2020; Muzaki \& Masjudin, 2019). Literasi lingkungan dan literasi matematis yang baik, diharapkan dapat meningkatkan kemampuan Computer Self Efficacy peserta didik dalam pembelajaran matematika. 
Jurnal Lebesgue: Jurnal Ilmiah Pendidikan Matematika, Matematika dan Statistika

M. Syaif Amrullah Alqusyairi, Farida, Suherman

Volume 2, No. 2, Agustus 2021 hal.153-165

DOI Artikel : 10.46306/lb.v2i2.62

Kemampuan Computer Self Efficacy sebagai suatu pendapat seseorang terkait kapabilitas dalam mengorganisasikan tugas atau kemampuan melaksanakan perilaku yang berkaitan dengan komputer (Bunyamin \& Sauda, 2019; Indah et al., 2021). Kemampuan dalam mengoperasikan komputer dalam menyelesaikan berbagai tugas menggunakan program software untuk menganalisis (Indah et al., 2021; Thahir et al., 2019). Kemampuan Computer Self Efficacy perlu dikuasai peserta didik dalam membatu menyelesaikan permasalahan matematika (Novindra \& Rasmini, 2017; Supiarmo et al., 2021).

Berdasarkan hasil studi pendahuluan yang telah dilakukan, diperoleh data bahwa masih rendahnya kemampuan literasi lingkungan, literasi matematis, dan kemampuan Computer Self Efficacy peserta didik. Peserta didik belum mampu menguraikan dan menyelesaiakan permasalahan matematis terkait lingkungan maupun keseharian, ketika peserta didik dihadapkan pada suatu soal cerita matematis yang diintegrasikan dengan permasalahan lingkungan peserta didik masih belum membiasakan untuk menulis apa yang diketahui dan yang menjadi pertanyaan dalam soal, sehingga masih sering terjadi salah penafsiran maksud dari soalnya, dan juga peserta didik masih ragu dahkan tidak sesekali untuk menggambarkan ilustrasi soal, akibatnya peserta didik sering kesulitan ketika menyelesaikan soal. Kemampuan literasi matematis dan literasi lingkungan pada diri peserta didik berpengaruh pada hasil belajarnya.

Beberapa penelitian relevan tentang literasi lingkungan, literasi matematis, dan kemampuan Computer Self Efficacy telah dilakukan oleh peneliti sebelumnya, diperoleh hasil bahwa terdapat peningkatan literasi lingkungan peserta didik melalui program Adiwiyata (Afrianda et al., 2019), kemudian terdapat peningkatan literasi matematis melalui model pembelajaran Problem Based Instruction (Fatwa et al., 2019), dan selanjutnya computer self efficacy, memiliki pengaruh positif bagi peserta didik dalam pembelajaran (Saufika \& Mahmud, 2018). Kekurangan dari beberapa penelitian tersebut yaitu masih belum terfokus dalam mendeskripsikan dan mengulas tentang literasi lingkungan, literasi matematis, dan kemampuan Computer Self Efficacy. Perbedaan penelitian tersebut dengan penelitian ini adalah peneliti akan meneliti hubungan literasi lingkungan dan literasi matematis terhadap kemampuan Computer Self Efficacy. Berdasarkan kajian tersebut, peneliti tertarik untuk melakukan penelitian dengan tujuan untuk melihat hubungan antara literasi lingkungan dan literasi matematis terhadap kemampuan Computer Self Efficacy peserta didik. 
Jurnal Lebesgue: Jurnal Ilmiah Pendidikan Matematika, Matematika dan Statistika

M. Syaif Amrullah Alqusyairi, Farida, Suherman

Volume 2, No. 2, Agustus 2021 hal.153-165

DOI Artikel : 10.46306/lb.v2i2.62

\section{METODE PENELITIAN}

Penelitian ini merupakan jenis penelitian kuantitatif dengan desain penelitian korelasional (Creswell, 2017). Penelitian ini bertujuan untuk mengetahui hubungan antara literasi lingkungan dan literasi matematis terhadap kemampuan Computer Self Efficacy peserta didik. Sampel dalam penelitian ini yaitu peserta didik kelas VIII MTs. Negeri 2 Tanggamus. Teknik pengumpulan data dalam penelitian ini menggunakan teknik tes dan angket. Instrumen penelitian menggunakan instrumen tes literasi lingkungan, tes literasi matematis, dan angket kemampuan Computer Self Efficacy.

Penelitian korelasional dilakukan melalui analisis Regresi Linear Sederhana dan Berganda yang mempermudah peneliti dalam peneltian. Teknik analisis data dalam penelitian ini meliputi uji normalitas, uji linearitas, uji multikolinearitas, uji heterokedastisitas, uji regresi linear sederhana, uji regresi linear berganda, koefisien determinasi $\left(R^{2}\right)$, uji parsial (Uji T), dan uji simultan (Uji F) (Novalia \& Syazali, 2014).

\section{HASIL DAN PEMBAHASAN}

Pengambilan data tes literasi lingkungan, tes literasi matematis, dan angket kemampuan Computer Self Efficacy dilakukan pada kelas kelas yang menjadi sampel penelitian. Data tes literasi lingkungan, tes literasi matematis, dan angket kemampuan Computer Self Efficacy adalah sebagai berikut:

Tabel 1. Deskripsi Data Amatan Literasi lingkungan, Literasi Matematis, dan Kemampuan Computer Self Efficacy

\begin{tabular}{|c|c|c|c|c|c|c|c|}
\hline \multirow[t]{2}{*}{ Data } & \multirow[t]{2}{*}{$\mathbf{X}_{\max }$} & \multirow[t]{2}{*}{$\mathbf{X}_{\min }$} & \multicolumn{3}{|c|}{$\begin{array}{c}\text { Ukuran Terdensi } \\
\text { Sentral }\end{array}$} & \multicolumn{2}{|c|}{$\begin{array}{c}\text { Ukuran } \\
\text { Variansi } \\
\text { Kelompok }\end{array}$} \\
\hline & & & $\overline{\mathbf{x}}$ & $\mathbf{M}_{\mathbf{o}}$ & $\mathbf{M}_{\mathbf{e}}$ & $\mathbf{R}$ & Sd \\
\hline Literasi lingkungan & 88,24 & 45,10 & 64,68 & 70,59 & 64,71 & 43,14 & 9,24 \\
\hline Literasi & 84,72 & 51,39 & 69,96 & 72,22 & 70,14 & 33,33 & 7,22 \\
\hline Computer Self Efficacy & 80,95 & 47,62 & 64,44 & 56,19 & 64,29 & 33,33 & 9,03 \\
\hline
\end{tabular}

Berdasarkan Tabel 2, hasil literasi matematis lebih baik dari hasil lingkungan dan angket kemampuan Computer Self Efficacy. hasil literasi matematis diperoleh nilai maksimum dan minimum masing-masing sebesar 84,72 dan 51,39, rata-rata nilai, median dan modus pada hasil literasi matematis masing-masing sebesar 69,96, 72,22, dan 70,14. Kesimpulannya bahwa literasi matematis sedikit lebih tinggi dari hasil literasi lingkungan dan angket kemampuan Computer Self Efficacy. 
Jurnal Lebesgue: Jurnal Ilmiah Pendidikan Matematika, Matematika dan Statistika

M. Syaif Amrullah Alqusyairi, Farida, Suherman

Volume 2, No. 2, Agustus 2021 hal.153-165

DOI Artikel : 10.46306/lb.v2i2.62

Tabel 7. Hasil Analisis Regresi Linear Sederhana (Literasi Lingkungan Terhadap Computer Self Efficacy)

\begin{tabular}{lr|r|r|r|r}
\hline \multicolumn{7}{c}{ Coefficients $^{\mathbf{a}}$} \\
\hline & $\begin{array}{c}\text { Unstandardized } \\
\text { Coefficients }\end{array}$ & $\begin{array}{c}\text { Standardize } \\
\mathbf{d} \\
\text { Coefficients }\end{array}$ & t & Sig. \\
\cline { 2 - 6 } Model & \multicolumn{1}{c|}{ B } & $\begin{array}{c}\text { Std. } \\
\text { Error }\end{array}$ & Beta & & \\
\hline (Constant) & 44,629 & 7,175 & & 6,220 &, 000 \\
\hline Literasi Lingkungan &, 305 &, 109 &, 316 & 2,788 &, 007 \\
\hline
\end{tabular}

a. Dependent Variable: Computer Self Efficacy

Berdasarkan Tabel 7, model persamaan regresi linier sederhana yang diperoleh adalah sebagai berikut:

$$
\widehat{Y}=44,629+0,305 X
$$

Nilai 44,629 adalah nilai kostanta yang berarti bahwa tidak terdapat kenaikan kemampuan Computer Self Efficacy, maka literasi lingkungan akan mencapai 44,629. Adapun nilai 0,305 adalah koefisien regresi yang apabila terjadi penambahan 1 angka dari kemampuan Computer Self Efficacy, maka akan terdapat kenaikan literasi lingkungan sebesar 0,305.

Analisis regresi linier sederhana yang berikutnya yaitu hubungan literasi matematis terhadap Computer Self Efficacy. Hasil uji regresi linier sederhana dapat dilihat pada tabel berikut:

Tabel 8. Hasil Analisis Regresi Linear Sederhana (Literasi Matematis Terhadap Computer Self Efficacy)

\begin{tabular}{|c|c|c|c|c|c|}
\hline \multicolumn{6}{|c|}{ Coefficients $^{\mathbf{a}}$} \\
\hline \multirow{2}{*}{ Model } & \multicolumn{2}{|c|}{$\begin{array}{l}\text { Unstandardized } \\
\text { Coefficients }\end{array}$} & \multirow{2}{*}{$\begin{array}{c}\begin{array}{c}\text { Standardize } \\
\text { d } \\
\text { Coefficients }\end{array} \\
\text { Beta }\end{array}$} & \multirow[t]{2}{*}{$\mathbf{t}$} & \multirow[t]{2}{*}{ Sig. } \\
\hline & B & $\begin{array}{c}\text { Std. } \\
\text { Error }\end{array}$ & & & \\
\hline (Constant) & 44,629 & 7,175 & & 6,220 &, 000 \\
\hline Literasi Matematis & ,305 & ,109 & ,316 & 2,788 &, 007 \\
\hline
\end{tabular}

a. Dependent Variable: Computer Self Efficacy

Berdasarkan Tabel 8, model persamaan regresi linier sederhana yang diperoleh adalah sebagai berikut:

$$
\widehat{Y}=34,749+0,424 X
$$

Nilai 34,749 merupakan nilai konstanta yang menunjukkan bahwa jika tidak terdapat kenaikan kemampuan Computer Self Efficacy, maka literasi matematis akan mencapai 34,749 Adapun nilai 0,424 merupakan koefisien regresi yang menunjukkan bahwa setiap ada 
Jurnal Lebesgue: Jurnal Ilmiah Pendidikan Matematika, Matematika dan Statistika

M. Syaif Amrullah Alqusyairi, Farida, Suherman

Volume 2, No. 2, Agustus 2021 hal.153-165

DOI Artikel : 10.46306/lb.v2i2.62

penambahan 1 angka untuk kemampuan Computer Self Efficacy, maka akan terdapat kenaikan literasi matematis sebesar 0,424.

Analisis Regresi Linier Berganda adalah hubungan secara linier antara dua atau lebih variabel independen $(X)$ dan variabel dependen $(Y)$. Analisi ini untuk mengetahui hubungan literasi lingkungan dan literasi matematis terhadap kemampuan Computer Self Efficacy peserta didik. Perhitungan uji Regresi Linear Berganda dalam penelitian ini menggunakan program SPSS. Hasil uji Regresi Linier Berganda dapat dilihat pada tabel berikut:

Tabel 9. Hasil Analisis Regresi Linear Berganda

\begin{tabular}{|c|c|c|c|c|c|}
\hline \multicolumn{6}{|c|}{ Coefficients $^{\mathrm{a}}$} \\
\hline \multirow{2}{*}{ Model } & \multicolumn{2}{|c|}{$\begin{array}{l}\text { Unstandardize } \\
\text { d Coefficients }\end{array}$} & \multirow{2}{*}{$\begin{array}{c}\begin{array}{c}\text { Standardized } \\
\text { Coefficients }\end{array} \\
\text { Beta }\end{array}$} & \multirow[t]{2}{*}{$\mathbf{t}$} & \multirow[t]{2}{*}{ Sig. } \\
\hline & B & $\begin{array}{l}\text { Std. } \\
\text { Error }\end{array}$ & & & \\
\hline (Constant) & 1,641 & 10,078 & & , 163 & ,871 \\
\hline Literasi lingkungan & ,446 & ,099 & ,441 & 4,497 &, 000 \\
\hline Literasi matematis & ,472 & , 138 & ,336 & 3,430 & ,001 \\
\hline
\end{tabular}

Berdasarkan Tabel 9 di atas, diperoleh juga persamaan regresi linier berganda adalah sebagai berikut:

$$
\widehat{Y}=1,641+0,446 X_{1}+0,472 X_{2}
$$

Nilai 1,641 yaitu nilai konstanta dimana jika tidak terdapat kenaikan kemampuan Computer Self Efficacy, maka literasi lingkungan dan literasi matematis akan mencapai 1,641. Nilai 0,446 merupakan koefisien regresi yang menunjukkan bahwa setiap ada penambahan 1 angka untuk kemampuan Computer Self Efficacy, maka akan terdapat kenaikan literasi lingkungan sebesar 0,446. Kemudian nilai 0,472 merupakan koefisien regresi yang menunjukkan bahwa setiap ada penambahan 1 angka untuk kemampuan Computer Self Efficacy, maka akan terdapat kenaikan literasi matematis sebesar 0,472.

Uji berikutnya yaitu uji koefisien determinasi $\left(R^{2}\right)$ pada intinya mengukur seberapa jauh literasi lingkungan dan literasi matematis dalam menerangkan variasi variabel kemampuan Computer Self Efficacy. Nilai koefisien determinasi adalah nol dari satu. Hasil dari koefisien determinasi $\left(R^{2}\right)$ dalam analisis Regresi Linear Berganda dapat dilihat pada tabel dibawah ini: Tabel 10. Hasil Koefisien Determinasi $\left(R^{2}\right)$

\begin{tabular}{|c|c|c|c|c|}
\hline \multicolumn{5}{|c|}{ Model Summary } \\
\hline Model & $\mathrm{R}$ & R Square & Adjusted R Square & $\begin{array}{l}\text { Std. Error of the } \\
\text { Estimate }\end{array}$ \\
\hline 1 &, $626^{\mathrm{a}}$ & ,392 & , 375 & 6,86966 \\
\hline \multicolumn{5}{|c|}{ a. Predictors: (Constant), Literasi matematis, Literasi lingkungan } \\
\hline \multicolumn{5}{|c|}{ Model Summaryb } \\
\hline
\end{tabular}


Berdasarkan Tabel 10, dapat dilihat bahwa hasil uji koefisien determinasi $\left(R^{2}\right)$ diperoleh hasil yaitu nilai $R^{2}=0,288$, artinya bahwa besar pengaruh dari literasi lingkungan dan literasi matematis terhadap kemampuan Computer Self Efficacy sebesar 39,2\%. Kesimpulannya besar pengaruh literasi lingkungan dan literasi matematis terhadap kemampuan Computer Self Efficacy yaitu sebesar 39,2\%.

Uji selanjutnya yang dilakukan dalam analisis Regresi Linear Berganda yaitu uji t. Uji t bertujuan untuk melihat hubungan dua variabel $X$ dengan variabel $Y$ secara parsial (sendiri). Hasil dari uji t dalam analisis Regresi Linear Berganda dapat dilihat pada tabel dibawah ini:

Tabel 11. Hasil Uji t dalam Analisis Regresi Linear Berganda

\begin{tabular}{lr|r|r|r|r}
\hline & \multicolumn{3}{c}{ Coefficients $^{\mathbf{a}}$} \\
\hline & $\begin{array}{c}\text { Unstandardize } \\
\text { d Coefficients }\end{array}$ & $\begin{array}{c}\text { Standardize } \\
\text { d Coefficients }\end{array}$ & t & Sig. \\
\cline { 2 - 7 } Model & \multicolumn{1}{|c|}{$\begin{array}{c}\text { Std. } \\
\text { Error }\end{array}$} & \multicolumn{1}{|c|}{ Beta } & & \\
\hline (Constant) & 1,641 & 10,078 & &, 163 &, 871 \\
\hline Literasi lingkungan &, 446 &, 099 &, 441 & 4,497 &, 000 \\
\hline Literasi matematis &, 472 &, 138 &, 336 & 3,430 &, 001 \\
\hline
\end{tabular}

Berdasarkan Tabel 11, dapat dilihat bahwa nilai nilai siginfikansi untuk hubungan literasi lingkungan terhadap kemampuan Computer Self Efficacy pada taraf signifikansi $a=0,05$, diperoleh nilai siginfikansi $=0,000$. Hal tersebut menunjukkan bahwa nilai siginfikansi $>$ 0,05, sehingga $H_{0 A}$ ditolak dan $H_{1 A}$ diterima. Kesimpulannya bahwa terdapat hubungan antara literasi lingkungan dengan kemampuan Computer Self Efficacy.

Kemudian berdasarkan Tabel 11, dapat dilihat bahwa nilai siginfikansi untuk hubungan literasi matematis terhadap kemampuan Computer Self Efficacy pada taraf signifikansi $a=$ 0,05 , diperoleh nilai siginfikansi $=0,001$. Hal tersebut menunjukkan bahwa nilai siginfikansi $<0,05$, sehingga $H_{0 B}$ ditolak dan $H_{1 B}$ diterima. Kesimpulannya bahwa terdapat hubungan antara literasi matematis dengan kemampuan Computer Self Efficacy.

Uji terakhir yang dilakukan dalam analisis Regresi Linear Berganda yaitu Uji F, uji F bertujuan untuk melihat pengaruh dua variabel $\mathrm{X}$ terhadap variabel $\mathrm{Y}$ secara simultan (bersamasama). Hasil dari uji F dalam analisis Regresi Linear Berganda dapat dilihat pada tabel dibawah ini:

Tabel 12. Hasil Uji F dalam Analisis Regresi Linear Berganda 


\begin{tabular}{l|l|l|l|l|l}
\hline \multicolumn{6}{c}{ ANOVA $^{\text {a }}$} \\
\hline Model & $\begin{array}{l}\text { Sum of } \\
\text { Squares }\end{array}$ & df & Mean Square & F & Sig. \\
\hline Regression & 2102,154 & 2 & 1051,077 & 22,272 &, $000^{\mathrm{b}}$ \\
\hline Residual & 3256,265 & 69 & 47,192 & & \\
\hline $\begin{array}{l}\text { Total } \\
\text { a. Dependent Variable: Computer Self Efficacy }\end{array}$ & & \\
\hline b. Predictors: (Constant), Literasi matematis, Literasi lingkungan \\
\hline
\end{tabular}

Berdasarkan Tabel 12, dapat dilihat bahwa nilai siginfikansi untuk hubungan literasi lingkungan dan literasi matematis terhadap kemampuan Computer Self Efficacy pada taraf signifikansi $a=0,05$, diperoleh nilai siginfikansi $=0,000$. Hal tersebut menunjukkan bahwa nilai siginfikansi $<0,05$, sehingga $H_{0 C}$ ditolak dan $H_{1 C}$ diterima. Kesimpulannya bahwa terdapat hubungan literasi lingkungan dan literasi matematis terhadap kemampuan Computer Self Efficacy.

Berdasarkan hasil penelitian yang diperoleh oleh peneliti, maka disimpulkan bahwa terdapat hubungan literasi lingkungan dan literasi matematis terhadap kemampuan Computer Self Efficacy. Hal tersebut dapat terjadi dikarenakan literasi lingkungan dan literasi matematis dapat berpengaruh secara signifikan terhadap kemampuan Computer Self Efficacy peserta didik.

Hasil penelitian yang diperoleh peneliti relevan dengan penelitian sebelumnya tentang literasi lingkungan, literasi matematis, dan kemampuan Computer Self Efficacy telah dilakukan oleh peneliti sebelumnya, diperoleh hasil bahwa terdapat peningkatan literasi lingkungan peserta didik melalui penerapan model Probem Based Learning, dan literasi lingkungan dapat meningkat melalui model PBL terintegrasi pembelajaran STEM (Anita et al., 2020). Kemudian terdapat peningkatan literasi matematis melalui pembelajaran Matematika Realistik berbasis Etnomatematika (Akbar et al., 2020), dan literasi matematis dapat meningkat melalui penerapan model kooperatif tipe Scramble dengan pendekatan kontekstual (Setiani \& Lukman, 2020). Selanjutnya terdapat pengaruh dimensi Computer Self Efficacy terhadap prestasi akademik mahasiswa (Bunyamin \& Sauda, 2019).

Proses penelitian dilakukan untuk melihat setiap indikator dari literasi lingkungan, literasi matematis, dan kemampuan Computer Self Efficacy peserta didik. Indikator dari literasi lingkungan meliputi pengetahuan lingkungan, sikap terhadap lingkungan, keterampilan kognitif, dan perilaku terhadap lingkungan. Kemudian indikator dari literasi matematis meliputi kemampuan ekspresi matematika berbentuk tulisan, merumuskan permasalahn nyata ke dalam model matematika, menyajikan masalah, adanya argumen yang sistematis dan logis serta dapat dipertanggungjawabkan, dapat merumuskan dan menyelesaikannya secara sitematis 
Jurnal Lebesgue: Jurnal Ilmiah Pendidikan Matematika, Matematika dan Statistika

M. Syaif Amrullah Alqusyairi, Farida, Suherman

Volume 2, No. 2, Agustus 2021 hal.153-165

DOI Artikel : 10.46306/lb.v2i2.62

menggunakan simbol dan perhitungan matematika. Selanjutnya indikator kemampuan individu karena sering menggunakan komputer, keyakinan tentang kepercayaan diri individu dalam menyelesaikan tugas-tugas komuterisasi terkait pelajaran matematika dengan baik, dan keyakinan pada kemampuan menggunakan softwere dan sistem ketika menghadapi situasi yang lebih sulit dan bervariasi dalam pembelajaran matematika.

Hasil analisis statistik deskriptif tentang kemampuan literasi lingkungan peserta didik kelas VIII SMP Negeri 1 Bandar Sribhawono secara umum masih tergolong dibawah rata-rata yaitu 64,68, kemudian nilai kemampuan literasi matematis peserta didik juga masih tergolong rata-rata yaitu 69,96, sedangkan nilai kemampuan Computer Self Efficacy peserta didik masih tergolong dibawah rata-rata yaitu 64,44. Merujuk dari hasil yang telah diperoleh, masih banyak peserta didik yang belum menguasai literasi lingkungan, literasi matematis, dan kemampuan Computer Self Efficacy. Oleh karena itu perlu ditingkatkannnya lagi kemampuan literasi lingkungan, literasi matematis, dan kemampuan Computer Self Efficacy peserta didik. Melalui hasil tersebut pendidik diharapkan dapat memberikan solusi terbaik dalam mengasah dan meningkatkan kemampuan literasi lingkungan, literasi matematis, dan kemampuan Computer Self Efficacy peserta didik. Oleh karena itu permasalahan ini perlu mendapat perhatian yang sungguh-sungguh mengingat peranan matematika yang begitu penting.

Hasil analisis Regresi Linear Beganda menunjukkan bahwa literasi lingkungan dan literasi matematis berpengaruh positif terhadap kemampuan Computer Self Efficacy peserta didik menghasilkan nilai koefisien determinasi 39,2\%, hal ini berarti bahwa 39,2\% kemampuan Computer Self Efficacy dapat ditentukan oleh literasi lingkungan dan literasi matematis secara bersama-sama, dengan asumsi bahwa pengaruh variabel-variabel lain diabaikan. Implikasinya adalah dengan kemampuan Computer Self Efficacy di bawah rata-rata tersebut, maka pengaruhnya positif adalah menjadikan kemampuan Computer Self Efficacy matematika peserta didik juga di bawah rata-rata.

Berdasarkan hasil uji t (uji untuk melihat hubungan dua variabel bebas dengan variabel terikat secara parsial (sendiri)) dalam analisis Regresi Linear Berganda, diperoleh kesimpulan bahwa terdapat hubungan antara literasi lingkungan dengan kemampuan Computer Self Efficacy. Hasil tersebut mengindikasikan bahwa hasil dari kemampuan Computer Self Efficacy juga sejalur dengan hasil penelitian literasi lingkungan peserta didik. Dalam penelitian ini dapat dilihat hasil nyata dari kemampuan Computer Self Efficacy dan literasi lingkungan peserta didik di sekolah (Widiyasari \& Achadiyah, 2019). Apabila kemampuan Computer Self Efficacy meningkat, maka literasi lingkungan juga akan meningkat dan begitu sebaliknya (Pratama et 
Jurnal Lebesgue: Jurnal Ilmiah Pendidikan Matematika, Matematika dan Statistika

M. Syaif Amrullah Alqusyairi, Farida, Suherman

Volume 2, No. 2, Agustus 2021 hal.153-165

DOI Artikel : 10.46306/lb.v2i2.62

al., 2020). Kemudian kesimpulan kedua yaitu terdapat hubungan antara literasi matematis dengan kemampuan Computer Self Efficacy peserta didik. Hasil tersebut juga mengindikasikan bahwa hasil dari kemampuan Computer Self Efficacy juga selaras dengan hasil penelitian literasi matematis peserta didik. Dalam penelitian ini dapat dilihat hasil nyata dari kemampuan Computer Self Efficacy dan literasi matematis peserta didik di sekolah (Safitri, 2021). Apabila kemampuan Computer Self Efficacy meningkat, maka literasi matematis juga akan meningkat dan begitupun sebaliknya (Hayati, 2020).

Selanjutnya hasil uji F (uji untuk melihat hubungan dua variabel bebas dengan variabel terikat secara simultan (bersama-sama)) dalam analisis Regresi Linear Berganda, diperoleh kesimpulan bahwa terdapat hubungan antara literasi lingkungan dan literasi matematis dengan kemampuan Computer Self Efficacy peserta didik. Hasil tersebut menunjukkan bahwa nilai dari kemampuan Computer Self Efficacy juga selaras dengan nilai penelitian literasi lingkungan dan literasi matematis peserta didik. Dalam penelitian ini dapat dilihat hasil nyata dari kemampuan Computer Self Efficacy, literasi lingkungan, dan literasi matematis didik di sekolah.(Bunyamin \& Sauda, 2019) Apabila kemampuan Computer Self Efficacy meningkat, maka literasi lingkungan dan literasi matematis juga akan meningkat dan begitupun sebaliknya. Kemampuan Computer Self Efficacy, literasi lingkungan, dan literasi matematis merupakan kemampuan matematika yang sangat penting dan perlu dikuasai peserta didik, karena kemampuan Computer Self Efficacy, literasi lingkungan, dan literasi matematis yang baik akan dapat menunjang peserta didik dalam belajar dan menyelesaikan berbagai permasalahan matematika.(Indah et al., 2021)

Model persamaan regresi linier berganda yang diperoleh yaitu $\hat{Y}=1,641+0,446 X_{1}+$ $0,472 X_{2}$. Hal tersebut dapat diartikan bahwa nilai 1,641 merupakan nilai konstanta yang menunjukkan bahwa jika tidak terdapat kenaikan kemampuan Computer Self Efficacy, maka literasi lingkungan dan literasi matematis akan mencapai 1,641. Adapun nilai 0,446 merupakan koefisien regresi yang menunjukkan bahwa setiap ada penambahan 1 angka untuk kemampuan Computer Self Efficacy, maka akan terdapat kenaikan literasi lingkungan sebesar 0,446. Kemudian nilai 0,472 merupakan koefisien regresi yang menunjukkan bahwa setiap ada penambahan 1 angka untuk kemampuan Computer Self Efficacy, maka akan terdapat kenaikan literasi matematis sebesar 0,472 .

\section{KESIMPULAN DAN SARAN}

Berdasarkan hasil penelitian dan pembahasan dalam penelitian ini, maka dapat disimpulkan bahwa Terdapat hubungan antara literasi lingkungan dengan kemampuan Computer Self 
Jurnal Lebesgue: Jurnal Ilmiah Pendidikan Matematika, Matematika dan Statistika

M. Syaif Amrullah Alqusyairi, Farida, Suherman

Volume 2, No. 2, Agustus 2021 hal.153-165

DOI Artikel : 10.46306/lb.v2i2.62

Efficacy peserta didik. Terdapat hubungan antara literasi matematis dengan kemampuan Computer Self Efficacy peserta didik. Terdapat hubungan antara literasi lingkungan dan literasi matematis dengan kemampuan Computer Self Efficacy peserta didik.

Peneliti mengharapkan kepada peneliti selanjutnya yang ingin meneliti tentang hubungan literasi lingkungan dan literasi matematis dengan kemampuan Computer Self Efficacy peserta didik, hendaknya dapat diperluas dan dapat memilih sampel penelitian yang lebih banyak lagi. Hal tersebut bertujuan untuk melihat tingkat keefektifan dalam meneliti hubungan literasi lingkungan dan literasi matematis dengan kemampuan Computer Self Efficacy peserta didik.

\section{DAFTAR PUSTAKA}

Afrianda, R., Yolida, B., \& Marpaung, R. R. (2019). Pengaruh Program Adiwiyata Terhadap Literasi Lingkungan dan Sikap Peduli Lingkungan. Jurnal Bioterdidik, 7(1), 32-42.

Akbar, P., Handayani, D., \& Mirza, A. (2020). Peningkatan Kemampuan Pemecahan Masalah Matematik Siswa Kelas 12 Pada Materi Dimensi Tiga Melalui Pendekatan Reciprocal Teaching. Jurnal Cendekia: Jurnal Pendidikan Matematika, 4(2), 900-913. https://doi.org/10.31004/cendekia.v4i2.330

Anita, Y., Nur, M., \& Nasir, M. (2020). Problem Based Learning Terintegrasi Pembelajaran Science, Technology, Engineering, and Mathematics (Stem) Terhadap Literasi Lingkungan Mahasiswa. BIOEDUKASI (Jurnal Pendidikan Biologi), 11(2), 105. https://doi.org/10.24127/bioedukasi.v11i2.3278

Bunyamin, M., \& Sauda, S. (2019). Pengaruh Dimensi Computer Self Efficacy (CSE) Terhadap Prestasi Akademik Mahasiswa. Jurnal Bina Komputer, 1(2), 133-139. https://doi.org/10.33557/binakomputer.v1i2.453

Creswell, J. W. (2017). Research Design Pendekatan Metode Kualitatif, Kuantitatif, dan Campuran. (2 ed.). Pustaka Pelajar.

Fatwa, V. C., Septian, A., \& Inayah, S. (2019). Kemampuan Literasi Matematis Siswa melalui Model Pembelajaran Problem Based Instruction. Mosharafa: Jurnal Pendidikan Matematika, 8(3), 389-398.

Ginanjar, A. Y., \& Widayanti, W. (2019). Penerapan Model Pembelajaran Multiliterasi Untuk Meningkatkan Kemampuan Literasi Matematis Siswa Di Sd/Mi. Primary: Jurnal Keilmuan dan Kependidikan Dasar, 10(2), 117-124. https://doi.org/10.32678/primary.v10i02.1283

Hapsari, T., Mujib, A., \& Firmansyah. (2019). Literasi Matematis Siswa Menggunakan Etnomatika Gordang Sembilan. Jurnal Ilmiah Pendidikan Matematika, 5(2), 173-184. https://doi.org/10.33603/e.v6i1.1885

Hayati, R. S. (2020). Pendidikan lingkungan berbasis experiential learning untuk meningkatkan literasi lingkungan. Humanika: Kajian Ilmiah Mata Kuliah Umum, 20(1), 63-82. https://doi.org/10.21831/hum.v20i1.29039

Hekmah, N., Wilujeng, I., \& Suryadarma, I. G. P. (2019). Web-Lembar Kerja Siswa IPA terintegrasi lingkungan untuk meningkatkan literasi lingkungan siswa. Jurnal Inovasi Pendidikan IPA, 5(2), 129-138. https://doi.org/10.21831/jipi.v5i2.25402

Hidayati, V. R., Wulandari, N. P., Maulyda, M. A., Erfan, M., \& Rosyidah, A. N. K. (2020). Literasi Matematika Calon Guru Sekolah Dasar dalam Menyelesaikan Masalah PISA Konten Shape \& Space. JPMI: Jurnal Pembelajaran Matematika Inovatif, 3(3), 1-10. 
Jurnal Lebesgue: Jurnal Ilmiah Pendidikan Matematika, Matematika dan Statistika

M. Syaif Amrullah Alqusyairi, Farida, Suherman

Volume 2, No. 2, Agustus 2021 hal.153-165

DOI Artikel : 10.46306/lb.v2i2.62

https://doi.org/10.22460/jpmi.v1i3.

Ilhami, A. (2019). Kontribusi Budaya Lokal Terhadap Literasi Lingkungan: Studi Kasus di SMP Pandam Gadang Sumatera Barat. Journal of Natural Science and Integration, 2(2), 122-131. https://doi.org/10.24014/jnsi.v2i2.7788

Indah, L., Rahmadhani, P., \& Mariani, S. (2021). Kemampuan Komputasional Siswa Dalam Memecahkan Masalah Matematika SMP Melalui Digital Project Based Learning Ditinjau Dari Self Efficacy. Prisma, Prosicing Seminar Nasional Matematika, 4, 289-297.

Indrawati, F. A., \& Wardono. (2019). Pengaruh Self Efficacy Terhadap Kemampuan Literasi Matematika dan Pembentukan Kemampuan 4C. Prisma, Prosiding Seminar Nasional Matematika, 2, 247-267. file:///C:/Users/sahabat/Downloads/29307-Article Text-669061-10-20190228.pdf

Janah, S. R., Suyitno, H., \& Rosyida, I. (2019). Pentingnya Literasi Matematika dan Berpikir Kritis Matematis dalam Menghadapi Abad ke-21. PRISMA, Prosiding Seminar Nasional Matematika, 2 , 905-910. https://journal.unnes.ac.id/sju/index.php/prisma/article/download/29305/12924

Komariah, N., M. Yusup, P., Saepudin, E., \& Rodiah, S. (2017). Pendidikan literasi lingkungan sebagai penunjang desa wisata agro Kecamatan Padaherang Kabupaten Pangandaran. Jurnal Aplikasi Ipteks untuk Masyarakat, 6(2), 111-115. http://jurnal.unpad.ac.id/dharmakarya/article/download/14781/7897

Komarudin, K., Rosmawati, N., \& Suherman, S. (2020). The Effect of Algebra Finger- Based Brain Gym Method to Improve Student Learning Outcomes. Eduma: Mathematics Education Learning and Teaching, 8(2), 80. https://doi.org/10.24235/eduma.v8i2.4202

Lestariningsih, Nurhayati, E., \& Cicinidia. (2020). Jenis Proses Berpikir Peserta Didik dalam Menyelesaikan Soal Literasi Matematis. Mosharafa: Jurnal Pendidikan Matematika, 9(1), 83-94.

Madyaratri, D. Y., Wardono, \& Prasetyo, A. P. B. (2019). Kemampuan Literasi Matematika Siswa pada Pembelajaran Problem Based Learning dengan Tinjauan Gaya Belajar. Prisma, Prosicing Seminar Nasional Matematika, 2, 648-658. https://journal.unnes.ac.id/sju/index.php/prisma/article/view/29213

Mujib, M., Mardiyah, M., Suherman, Rakhmawati, R., Andriani, S., Mardiyah, M., Suyitno, H., Sukestiyarno, S., \& Junaidi, I. (2019). The Application of Differential Equation of Verhulst Population Model on Estimation of Bandar Lampung Population. Journal of Physics: $\quad$ Conference Series, 1155(1), 1-6. https://doi.org/10.1088/1742$6596 / 1155 / 1 / 012017$

Muzaki, A., \& Masjudin. (2019). Analisis Kemampuan Literasi Matematis Siswa. Jurnal Pendidikan Matematika, 8(3), 493-502.

Novalia, \& Syazali, M. (2014). Olah Data Penelitian Pendidikan. Anugrah Utama Raharja (AURA).

Novindra, N. P. B., \& Rasmini, N. K. (2017). Pengaruh Kemudahan Penggunaan, Persepsi Kegunaan, Dan Computer Self Efficacy Pada Minat Penggunaan E-Spt. E-Jurnal Akuntansi, 19(2), 1116-1143.

Nugraha, F., Permanasari, A., \& Pursitasari, I. D. (2021). Disparitas Literasi Lingkungan Siswa Sekolah Dasar di Kota Bogor. Jurnal IPA dan Pembelajaran IPA, 5(1), 15-35. https://doi.org/10.24815/jipi.v5i1.17744

Pamungkas, M. D., \& Franita, Y. (2019). Keefektifan Problem Based Learning Untuk Meningkatkan Kemampuan Literasi Matematika Siswa. Jurnal Penelitian Pendidikan dan Pengajaran Matematika, 5(2), 75-80. http://jurnal.unsil.ac.id/index.php/jp3m/article/view/MEG52

Prabawati, M. N., Herman, T., \& Turmudi. (2019). Pengembangan LKS berbasis Masalah 
dengan Strategi Heuristic untuk Meningkatkan Kemampuan Literasi Matematis. Mosharafa: Jurnal Pendidikan Matematika, 8(1), 37-48.

Pratama, A. Y., Marpaung, R. R. T., \& Yolida, B. (2020). Pengaruh Literasi Lingkungan terhadap Environmental Responsibility Siswa Kelas XI SMA Negeri 2 Bandar Lampung. Jurnal Bioterdidik: Wahana Ekspresi Ilmiah, 8(1), 56-65. https://doi.org/10.23960/jbt.v8.i1.07

Rahmah, S., Puspitasari, R., Lubis, R., \& Festiyed. (2019). Analisis Buku Ajar Ipa Smp Kelas Viii Berdasarkan Pada Literasi Lingkungan. Pillar of Physics Education, 12(3), 601-608.

Safitri, I. (2021). Pengaruh Blended Learning Terhadap Peningkatan Literasi Matematika Siswa. Jurnal Cendekia: Jurnal Pendidikan Matematika, 5(1), 735-743.

Saufika, F., \& Mahmud, A. (2018). Peran Minat Belajar Dalam Memediasi Pengaruh Computer Self-Efficacydan Penggunaan Internet Terhadap Prestasi Belajar. Economic Education Analysis Journal, 7(3), 816-831.

Setiani, A., \& Lukman, H. S. (2020). Meningkatan Kemampuan Pemecahan Masalah Matematis Menggunakan Strategi Problem Based Learning Berbantuan Mind Mapping. PRISMA, 9(2), 128-135.

Suherman, Prananda, M. R., Proboningrum, D. I., Pratama, E. R., Laksono, P., \& Amiruddin. (2020). Improving Higher Order Thinking Skills (HOTS) with Project Based Learning (PjBL) Model Assisted by Geogebra. Journal of Physics: Conference Series, 1467(1), 110. https://doi.org/10.1088/1742-6596/1467/1/012027

Sukaesih, E. S., Indiati, I., \& Purwosetiyono, F. X. D. (2020). Kemampuan Pemahaman Konsep Matematis Siswa dalam Memecahkan Masalah Kontekstual Ditinjau dari Komunikasi Matematis Siswa. Imajiner: Jurnal Matematika dan Pendidikan Matematika, 2(4), 310320.

Supiarmo, M. G., Mardhiyatirrahmah, L., \& Turmudi. (2021). Pemberian Scaffolding untuk Memperbaiki Proses Berpikir Komputasional Siswa dalam Memecahkan Masalah Matematika. Jurnal Cendekia: Jurnal Pendidikan Matematika, 5(1), 368-382.

Supriyanto, A. (2020). Model Pengembangan Penguatan Pendidikan Karakter dan Literasi Lingkungan. Jurnal Ilmiah Pendidikan Pancasila dan Kewarganegaraan, 5(1), 17-23. https://doi.org/10.17977/um019v5i1p17-23

Thahir, A., Komarudin, Hasanah, U. N., \& Rahmahwaty. (2019). MURDER learning models and self efficacy: Impact on mathematical reflective thinking ability. Journal for the Education of Gifted Young Scientists, 7(4), 1120-1133. https://doi.org/10.17478/jegys.594709

Widiyasari, R., \& Achadiyah, B. N. (2019). Computer Anxiety, Computer Self-Efficacy dan Perceived Usefulness oleh Pelaku UMKM. Jurnal Akuntansi Aktual, 5(3), 203-214. https://doi.org/10.17977/um004v5i32019p203

Wijaya, I. K. W. B. (2019). Eco Family : Metode Parenting Anak Usia Dini Untuk Membentuk Generasi Literasi Lingku. Jurnal Pendidikan Anak Usia Dini, 4(1), 40-49.

Yusliani, E., \& Yanti, Y. (2020). Meta-Analisis Pengembangan Modul Pembelajaran Terintegrasi Literasi Lingkungan. Jurnal Penelitian dan Pembelajaran Fisika, 6(2), 112 119. http://ejournal.unp.ac.id/index.php/jppf/article/view/108591 